\title{
19. NEOGENE PLANKTONIC FORAMINIFERAL STRATIGRAPHY IN DEEP-SEA DRILLING SITES, SOUTHEAST INDIAN OCEAN
}

\author{
J. P. Kennett, Graduate School of Oceanography, University of Rhode Island, Kingston, Rhode Island
}

\section{INTRODUCTION}

Leg 28 of the Deep Sea Drilling Project was the first Deep Sea Drilling leg to drill in Antarctic waters where 16 holes were drilled at 11 sites. This contribution is a brief report of the planktonic foraminiferal biostratigraphy at three sites $(264,265,266)$ located to the south of Western Australia. Due to the high latitude location of most of the 16 sites, the foraminiferal diversity is very low and calcium carbonate dissolution is very high. At sites where the planktonic foraminiferal faunas are particularly dissolved, attempts to determine a planktonic foraminiferal biostratigraphy are difficult. The planktonic foraminiferal biostratigraphy of the Neogene has been determined in three sites of Leg 28 containing a planktonic foraminiferal record. One of these sites (Site 264) is adjacent to the southwest part of Australia and lies in present-day water masses intermediate between cool subtropical (temperate) and warm subtropical conditions. The other two sites (Sites $265,266)$ lie to the south of the present-day position of the Antarctic Convergence and hence are true Antarctic sites. Sites 265 and 266 are the first two sites to be drilled in Antarctic waters.

The relative abundances of the planktonic foraminifera have been determined for the Neogene of these three sites in the size fraction greater than $147 \mu$. The biostratigraphic data for Sites 264 and 265 are shown in Tables 1 and 2, respectively.

\section{HOLE 264, 264A}

(lat $34^{\circ} 58.01$ 'S; long $112^{\circ} 02.8^{\prime} \mathrm{E}$; water depth $2873 \mathrm{~m}$ )

Site 264 was cored near the southern edge of the Naturaliste Plateau. The late Cenozoic sediments consist of an early Pliocene to Recent sequence of 31 meters of foram-bearing to foram-nanno ooze. This sequence is disconformably underlain by nanno ooze of late middle Eocene age. The location of Site 264, transitional between temperate and warm subtropical water masses, makes it particularly significant. Sites with transitional faunas between these two water masses are uncommon and provide useful insight into the correlation of temperate with tropical late Cenozoic biostratigraphics.

The planktonic foraminifera at Site 264 are abundant in all the samples examined (Table 1). Preservation was good except in the early Pliocene Core 2, Section 3, where dissolution caused fragmentation of the foraminiferal tests and preferentially concentrated species with high resistance to calcium carbonate dissolution. The upper 18 meters $(264-1 ; 264 A-1)$ are of Pleistocene age based on the presence of Globorotalia truncatulinoides and Neoglogoquadrina dutertrei dutertrei throughout and the absence of Pliocene foraminifera. Neogloboquadrina pachyderma is almost completely dextral coiled in the Pleistocene interval. A compressed late Pliocene to early Plioecne sequence is represented by Cores 264A-2 to Hole 264, Core 2, Section $3(13 \mathrm{~m})$. Hole 264A, Core 2, Section 3 is of late Pliocene age based on the presence of rare Globorotalia tosaensis, the absence of Globorotalia truncatulinoides and Neogloboquadrina dutertrei dutertrei, and the presence of Globoquadrina altispira. Hole 264A, Core 2, Section 6 is of middle Pliocene age based on the absence of Globorotalia tosaensis and the combined presence of both Globorotalia inflata and Globorotalia puncticulata. Kennett (1973) has demonstrated that the evolution of Globorotalia puncticulata to Globorotalia inflata takes place within the middle Pliocene in temperate to warm subtropical sites in the southwest Pacific. In these samples Globorotalia inflata specimens are morphologically close to Globorotalia puncticulata in having less rounded tests and reduced apertural size compared with advanced Globorotalia inflata. Compressed specimens of $G$. inflata that occur within this integrading assemblage are morphologically closer to $G$. puncticulata with four chambers in the final whorl.

In the middle and late Pliocene samples examined, the Neogloboquadrina pachyderma population contains both sinistral and dextral coiling forms. Hole 264, Core 2, Section 3 is clearly of early Pliocene age based on the occurrence of Globorotalia puncticulata, Globorotalia crassaformis, Globorotalia margaritae, Globorotalia cf. conoidea, Globigerina nepenthes, and the absence of Globorotalia inflata. The first appearance of Globorotalia puncticulata is considered by Kennett (1973) to mark the boundary between the Kapitean (late Miocene) and the Opoitian (early Pliocene) stages in the New Zealand region. Furthermore, Globorotalia margaritae is considered by Bolli (1970) and Cita (1973) to be the most characteristic early Pliocene foraminifera in warm subtropical and tropical regions. Cita (1973) has demonstrated that the first appearance of Globorotalia margaritae coincides with the MiocenePliocene boundary in the Mediterranean region. The importance of Globorotalia margaritae for distinguishing early Pliocene sediments in the Indian Ocean region has also been demonstrated by Srinivasan and Srivastava (in press) and by Kennett and Srinivasan (in press). Another typically early Pliocene form present is Globorotalia cf. conoidea. This form has been reported as being restricted to the early Pliocene in deep-drilled sites of the southwest Pacific (Kennett, 1973). The absence of Globorotalia cibaoensis in the early Pliocene suggests that the assemblage is not of earliest Pliocene age because this form is typical of earliest Pliocene and latest Miocene sediments of deep-drilled sites in the 
TABLE 1

Distribution of Planktonic Foraminifera in the Late Cenozoic of Holes 264 and 264A

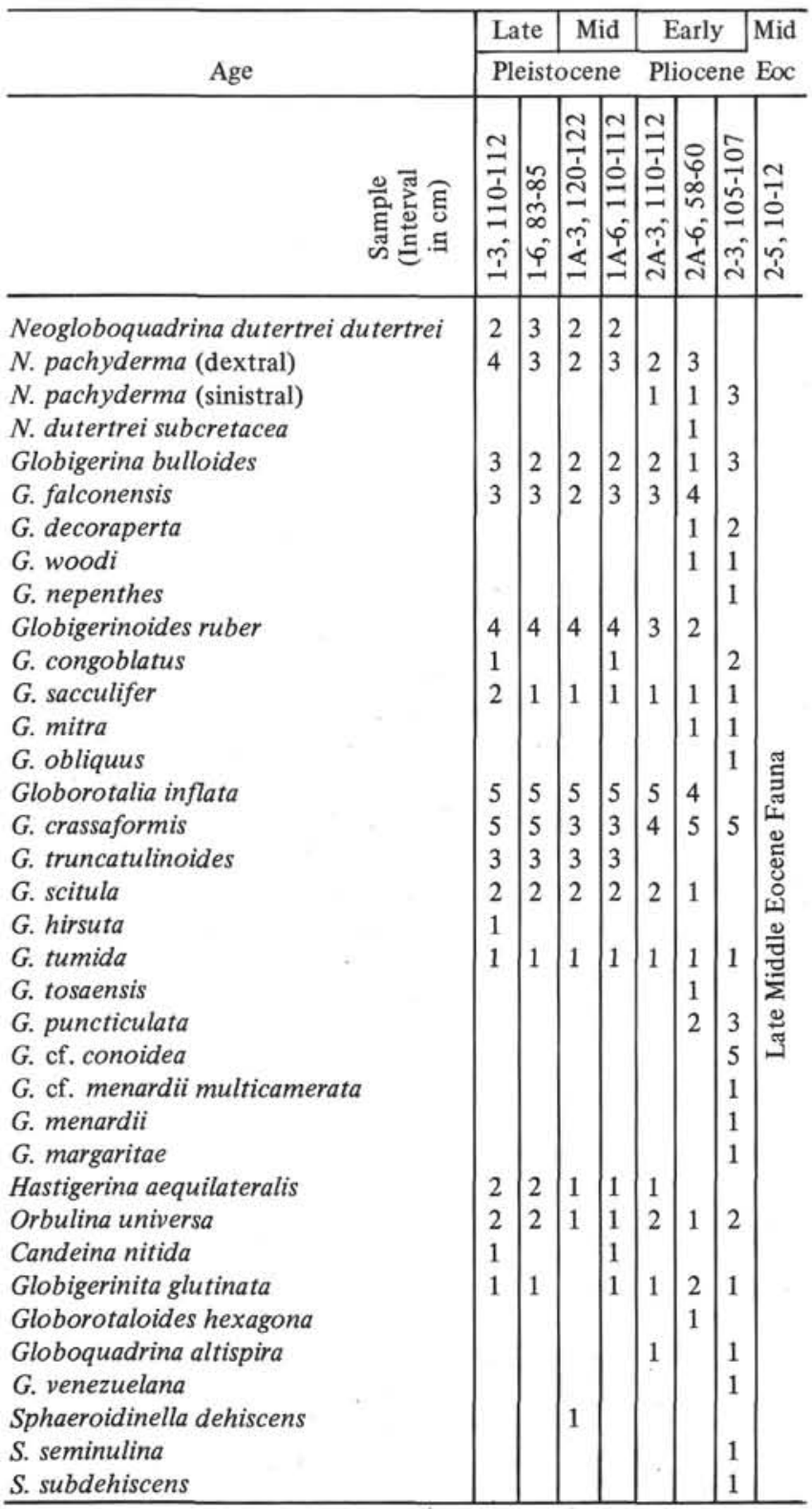

Note: Number of specimens for each species in the $>147 \mu$ fraction is shown as follows: $1=1-10 ; 2=11-25 ; 3=26-50 ; 4=51-100 ; 5=$ $>100$.

southwest Pacific (Kennett, 1973). Hole 264, Core 2, Section 3 also contains a few specimens of the middle Eocene foraminifera, Acarinina primitiva, apparently as the result of upward bioturbation from the underlying late middle Eocene sediments. Sample 264-2-5, 10-12 cm contains A. primitiva in abundance, and Globigerapsis index, Globorotaloides turgida, and Globigerina linaper$t a$. Such an assemblage is of late middle Eocene age and correlates with the Bortonian State of New Zealand (Jenkins, 1971).

The dominance of Globorotalia inflata-Globorotalia puncticulata plexus throughout the late Cenozoic, the
TABLE 2

Distribution of Neogene Planktonic

Foraminifera, Zones, and Ages at Site 265

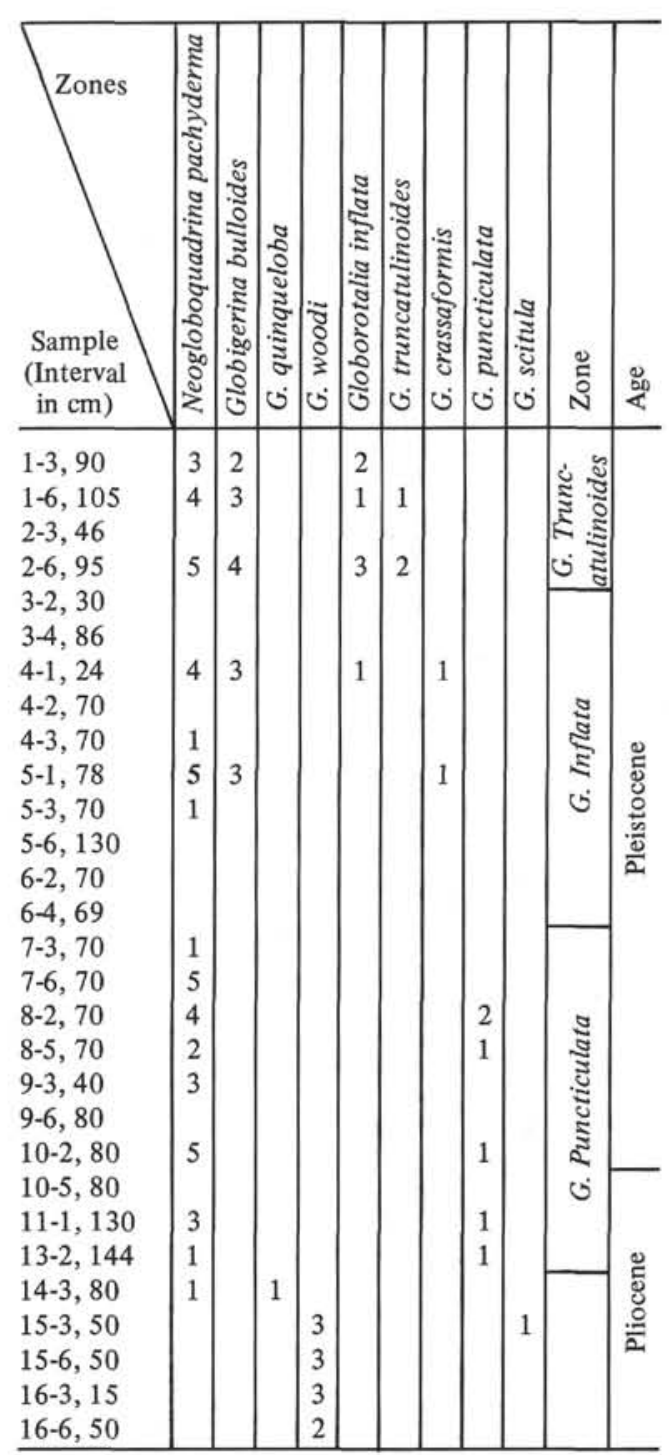

Note: Number of specimens for each species in the $>147 \mu$ fraction is shown as follows: $1=1-10 ; 2$ $=11-25 ; 3=26-50 ; 4=51-100 ; 5=>100$.

consistently common presence of Neogloboquadrina pachyderma, and the relatively rare but still consistent occurrences of warm subtropical to temperate foraminifera such as Globorotalia tumida and $G$. menardii suggest that the Neogene faunas at Site 264 are of a warm temperate type or intermediate in nature between cool subtropical and warm subtropical. It is important to note that the coiling direction in Neogloboquadrina pachyderma is almost exclusively sinistral in the early Pliocene, is both sinistral and dextral in the middle and late Pliocene, and is almost exclusively dextral throughout the Pleistocene. The early Pliocene sinistral population of Neogloboquadrina pachyderma occurs in association with warm-water forms such as Globorotalia menardii, G. margaritae, Sphaeroidinella seminulina, and 
Sphaeroidinella subdehiscens which suggests that the leftcoiling characteristic in the early Pliocene $N$. pachyder$m a$ assemblages is not climatically controlled.

\section{SITE 265}

(lat $53^{\circ} 32.45^{\prime} \mathrm{S}$; long $10^{\circ} 56.74^{\prime} \mathrm{E}$; water depth $3552 \mathrm{~m}$ )

Site 265 is located $500 \mathrm{~km}$ south of the Southeast Indian Ridge crest and approximately 3-400 km south of the present position of the Antarctic Convergence. This site is thus in true Antarctic waters. The planktonic foraminiferal record at this site is incomplete due to substantial calcium carbonate dissolution at numerous intervals. However, a sufficient number of samples in the Neogene contain enough planktonic foraminifera to determine the general planktonic foraminiferal biostratigraphy of the Antarctic during the late Cenozoic. About one half (or $50 \%$ ) of the samples examined are barren or essentially barren of planktonic foraminifera; other levels have abundant faunas. Diversity is very low throughout the sequence with a maximum of four species present at any interval. Calcium carbonate dissolution has caused substantial test breakage throughout the greater portion of the site. Critical zonal species are often very rare, but present in sufficient numbers to permit a general biostratigraphic zonation to be recognizable. Planktonic foraminiferal occurrences are plotted in Table 2. The threefold planktonic foraminiferal zonation for the PlioPleistocene of the Antarctic region can be recognized at Site 265 (Kennett, 1970; Keany and Kennett, 1972). The upper zone is marked by the occurrence of Globorotalia truncatulinoides (Core 1, Section 3 to Core 2, Section 6). The G. truncatulinoides Zone in Antarctic waters is much younger in age than that in temperate to subtropical water masses (Kennett, 1970) and is considered to reflect a later migration $(200,000$ yr B.P.) of truncatulinoides into the Antarctic water mass. The underlying Globorotalia inflata Zone is marked by the presence of $G$. inflata and $G$. crassaformis without $G$. truncatulinoides or $G$. puncticulata. The base of the $G$. inflata Zone closely coincides with the Brunhes-Matuyama boundary (0.69 m.y.B.P.) (Kennett, 1970; Keany and Kennett, 1972). Underlying the $G$. inflata Zone is the $G$. puncticulata Zone which is distinguished by the occurrence of $G$. puncticulata and the absence of $G$. inflata and G. crassaformis. At Site 265, the oldest occurrence of G. puncticulata is in Core 13, Section 2, which is of late Pliocene age. This level may represent the first occurrence of $G$. puncticulata in Antarctic waters, but confirmation is needed from other Antarctic biostratigraphic sequences. An additional zone underlying the $G$. puncticulata Zone can be distinguished based on the presence of Globigerina woodi. The $G$. woodi Zone is of early Pliocene and possibly late Miocene age, judging from the radiolarian biostratigraphic sequence. The first appearance of Neogloboquadrina pachyderma at Site 265 is close to the base of the G. puncticulata Zone. Possibly $N$. pachyderma first appeared in Antarctic waters within the Pliocene and thus much later than its first evolutionary occurrence in temperate regions to the north in the late Miocene. Although the early Pliocenelate Miocene faunas contain abundant assemblages of
G. woodi, no $N$. pachyderma were found in association. This fact suggests that the first appearance of $N$. pachyderma in Antarctic waters did indeed occur near the end of the $G$. woodi range and near the beginning of the $G$. puncticulata range in Antarctic waters. The very low diversity of the planktonic foraminifera throughout the Plio-Pleistocene sequence of the Antarctic sediments reflect the extremely cold conditions that have prevailed throughout this interval in Antarctic waters. The PlioPleistocene boundary at Site 265 occurs within the $G$. puncticulata Zone and is marked by the extinction of Clathrocyclas bicornis, which also coincides with the base of the Gilsa Event (Hays and Opdyke, 1967) at 1.79 m.y.B.P. (Cox, 1969) within the Matuyama reversed epoch.

\section{SITE 266}

(lat $5^{\circ}{ }^{\circ} 2.13$ 'S ; long $110^{\circ} 06.70^{\prime} \mathrm{E}$; water depth $4173 \mathrm{~m}$ )

Site 266 lies approximately $800 \mathrm{~km}$ south of the Southeast Indian Ridge crest and $600-700 \mathrm{~km}$ south of the present position of the Antarctic Convergence. Thirty-two samples were examined from Cores 1 to 23 . Of these cores, 21 are barren of planktonic foraminifera, although rich radiolarian faunas are contained. Sample $1-3,75-77 \mathrm{~cm}$ is of Brunhes normal epoch age and contains a poor fauna consisting of $N$. pachyderma and Globigerina bulloides. Sample 2-3, $120 \mathrm{~cm}$ contains a rich $N$. pachyderma fauna containing one specimen of $G$. puncticulata and indicating a Matuyama (late Plioceneearly Pleistocene) age. Sample 13-3, 40-42 cm contains an abundant fauna of Globorotalia zealandica and Globigerina woodi suggesting a middle Miocene age. Sample 16-2, 88-90 cm contains a poor fauna of Catapsydrax dissimilis and Globigerina species. The presence of Catapsydrax dissimilis indicates a late Oligocene to early Miocene age (Jenkins, 1970). Several samples between $18-2,30-32 \mathrm{~cm}$ to $23-1,25-27 \mathrm{~cm}$ contain poor faunas of $C$. dissimilis except in two samples containing Globigerina species. This is the only species present and gives an age of late Oligocene to early Miocene. Site 266 represents a sequence that has undergone substantial calcium carbonate dissolution throughout the Neogene. The very low diversity of the Neogene planktonic foraminiferal faunas suggests extremely cool conditions within the Antarctic over this time interval. Although the high degree of dissolution may have contributed to the low diversity by eliminating possible delicate species, a few levels do occur in the Neogene sequence that contain moderately abundant planktonic foraminiferal faunas. These intervals show the same very low diversity that is characteristic of this site.

\section{ACKNOWLEDGMENTS}

This research was partially supported by National Science Foundation GV-28305 (Office of Polar Programs).

\section{REFERENCES}

Bolli, H. M., 1970. The Foraminifera of Sites 23-31, Leg 4. In Bader, R. G., et al., Initial Reports of the Deep Sea Drilling Project, Volume 4: Washington (U.S. Government Printing Office), p. 577. 
Cita, M. B., 1973. Pliocene biostratigraphy and chronostratigraphy, DSDP Leg 13. In Ryan, W. B. F., Hsu, K. J., et al., Initial Reports of the Deep Sea Drilling Project, Volume 8: Washington (U.S. Government Printing Office), p. 1343.

Cox, A., 1969. Geomagnetic Reversals: Science, v. 163, p. 237.

Hays, J. D. and Opdyke, N. D., 1967. Antarctic Radiolaria, magnetic reversals, and climatic change: Science, v. 157, p. 1001.

Jenkins, D. G., 1971. New Zealand Cenozoic planktonic foraminifera: New Zealand Geol. Surv. Bull., v. 42, p. 1.

Keany, J. and Kennett, J. P., 1972. Pliocene-early Pliocene paleoclimatic history recorded in Antarctic-Subantarctic deep-sea cores: Deep-Sea Res., v. 19, p. 529.
Kennett, J. P., 1970. Pleistocene paleoclimates and foraminiferal biostratigraphy in Sub-antarctic deep-sea cores: Deep-Sea Res., v. 17, p. 125.

1973. Middle and late Cenozoic planktonic foraminiferal biostratigraphy of the Southwest Pacific, DSDP Leg 21. In Burns, R. E., Andrews, J. E., et al., Initial Reports of the Deep Sea Drilling Project, Volume 21: Washington (U.S. Government Printing Office), p. 575.

Kennett, J. P. and Srinivasan, M. S., in press. Stratigraphic occurrences of the Miocene Planktonic foraminifera Globoquadrina dehiscens in Early Pliocene sediment of the Indian Ocean: Rev. Espanola Micropaleontol.

Srinivasan, M. S. and Srivastava, S. S., 1974. Sphaeroidinella dehiscens datum and the Miocene-Pliocene boundary: Am. Assoc. Petrol. Geol. Bull., v. 58, p. 304. 